\title{
Circulating levels of gonadotrophins in immature mice treated neonatally with antisera to gonadotrophins
}

\author{
Vijaya Raghavan, Tarala V. Purandare, A. R. Sheth and Safia R. Munshi \\ Institute for Research in Reproduction (ICMR), Jehangir Merwanji Street, \\ Parel, Bombay 400 012, India
}

The circulating levels of gonadotrophins in immature and adult rats have been studied by several workers (Weisz \& Ferin, 1970; Goldman, Grazia, Kamberi \& Porter, 1971 ; Ojeda \& Ramirez, 1972; Dohler \& Wuttke, 1974, 1975). We have shown that administration of antigonadotrophic sera to neonatal mice affects ovarian development (Purandare, Munshi \& Rao, 1976). In the present study the changes in gonadotrophin levels after treatment of neonatal mice wth such antisera were examined.

Inbred female mice of the Swiss strain were maintained in air-conditioned rooms $\left(24^{\circ} \mathrm{C}\right.$, relative humidity $50-60 \%$. The lighting schedule was $14 \mathrm{~h}$ light $/ 24 \mathrm{~h}$. The animals were fed an appropriate commercial diet (Hindustan Lever) and tap water was available. At 5 days of age females were injected with $0.1 \mathrm{ml}$ antiserum to ovine FSH or $0.1 \mathrm{ml}$ antiserum to ovine LH. Control animals received $0.1 \mathrm{ml}$ normal rabbit serum (NRS). The young remained with the mother until weaning at 21 days of age. Animals were anaesthetized with ether at the time of collection of blood. Pooled plasma samples were obtained from females at $5,7,10,14,17,21$ and 28 days after birth and stored at $-20^{\circ} \mathrm{C}$ until assayed. Plasma FSH and LH were measured by means of the NIAMDD radioimmunoassay kits for rat FSH and rat LH, which have been validated for use in the mouse by Beamer, Murr \& Geshwind (1972). Each assay had a sensitivity of $5 \mathrm{ng} / \mathrm{ml}$ and the results are expressed as $\mathrm{ng}$ equivalents of the NIH-Rat-LH-S1 or NIH-Rat-FSH-S1 standards. Each sample was run at two dilutions, 50 and $100 \mu 1$ (in duplicate) for FSH and 10 and $100 \mu \mathrm{l}$ for LH. All the samples were analysed in a single assay to avoid intra-assay errors. The interassay variations were $10.3 \%$ and $12 \%$ for FSH and LH assays, respectively.

Circulating antibodies which might have interfered with the assays were removed so that the levels of unbound FSH and LH could be accurately measured. An immunoadsorbent of anti-rabbit gamma globulin was prepared by the technique of Avramaes \& Ternynck (1969) and incubated overnight at $4^{\circ} \mathrm{C}$ with the samples which were then centrifuged at $2000 \mathrm{~g}$ for $30 \mathrm{~min}$ at $4^{\circ} \mathrm{C}$. For the detection of circulating antibodies, the plasma samples were incubated with the labelled hormone alone and then precipitated with anti-rabbit gamma globulin. There was no precipitation of the labelled antigen if the antibodies had been removed completely by the immunoadsorbent.

In the present study, the LH levels in intact neonatal Swiss female mice reached a peak at about Day 14 of age and FSH levels were highest between Days 10 and 14 (Table 1). Dullaart, Kent \& Ryle (1975) observed maximum LH levels between Days 8 and 12 and FSH levels between Days 12 and 15 in outbred CFW mice, while Stiff, Bronson \& Stetson (1974) observed an increase in LH and FSH concentrations by Day 10 in CF-1 mice. A similar variation has been reported for rats, maximum LH levels being found at Days 10, 14 and 21 by Weisz \& Ferin (1970), Ojeda \& Ramirez (1972) and Dohler \& Wuttke $(1974,1975)$, respectively, and maximum FSH levels at Days 7-14 (Weisz \& Ferrin, 1970) or Days 12-15 (Kragt \& Dahlgren, 1972; Dohler \& Wuttke, 1974, 1975). The higher levels of gonadotrophins in neonatal and juvenile rodents than in the adult animal are believed to be involved in the organization of the CNS (Sheridan, Zarrow \& Denenberg, 1973).

When antiserum to ovine $\mathbf{L H}$ was injected on Day 5 , the levels of circulating $\mathbf{L H}$ were undetectable until Day 14 of age when approximately $47 \%$ of the circulating LH was neutralized. LH levels then decreased gradually, but were similar to or higher than those in the control animals.

In the animals treated with antiserum to ovine FSH, the FSH levels were undetectable until Day 14 when $54 \%$ of the plasma FSH was neutralized. The FSH levels then increased about 3-fold on Days 17 and 21 when compared to those on Day 14, and were 8 times higher than those of the control animals 
Table 1. Circulating levels of LH and FSH in mice treated with antisera to LH and FSH

\begin{tabular}{|c|c|c|c|c|}
\hline \multirow[b]{2}{*}{$\begin{array}{c}\text { Age } \\
\text { (days) }\end{array}$} & \multicolumn{2}{|c|}{ LH (ng/ml) } & \multicolumn{2}{|c|}{ FSH $(\mathrm{ng} / \mathrm{ml})$} \\
\hline & Controls & $\begin{array}{l}\text { Antiserum } \\
\text { to } \mathrm{LH}\end{array}$ & Controls & $\begin{array}{c}\text { Antiserum } \\
\text { to FSH }\end{array}$ \\
\hline 5 & $910(30)$ & - & $1840(30)$ & - \\
\hline 7 & $1000(28)$ & $0(20)$ & $2880(28)$ & $0(28)$ \\
\hline 10 & $2300(30)$ & $0(30)$ & $3800(30)$ & $0(30)$ \\
\hline 14 & 8000 (29) & $3800(28)$ & $3200(29)$ & $1720(28)$ \\
\hline 17 & $920(22)$ & $2050(25)$ & $2000(22)$ & $5100(25)$ \\
\hline 21 & $1000(22)$ & $980(22)$ & $560(22)$ & $4600(22)$ \\
\hline 28 & $360(20)$ & $1075(20)$ & $680(20)$ & $1150(20)$ \\
\hline 90 & $200-560(10)$ & - & $200-700(10)$ & - \\
\hline
\end{tabular}

The numbers in parentheses indicate the numbers of animals in each pool.

at Day 21 of age. Although there was a decline on Day 28, the level was still higher than that observed in the control animals of the same age.

In the mice treated with antisera to gonadotrophins the endogenous gonadotrophins appeared to be completely neutralized until Day 10 of age and partly neutralized at Day 14 . This finding agrees with our histological observations that ovarian development at Day 14 of age is inhibited in similarly treated mice (Purandare et al., 1976). The present findings also explain the enhanced follicular development and increased ovarian weight of such mice at Day 21 of age (Purandare et al., 1976).

Antibodies to LH and FSH were still in the circulation of treated animals at Day 28 of age (Table 2). Anderson, Schwartz, Nequin \& Ely (1976) have also reported circulating antibodies to be present in rats until Day 49, when the antiserum injections were given from Days 5 to 15 of age. It is surprising that, although the antibodies are present in the circulation for such a long time, they are not able to neutralize the endogenous hormone. Anderson et al. (1976) suggested that the injected antiserum forms soluble complexes with the circulating gonadotrophins.

Table 2. Circulating antibodies to $\mathrm{LH}$ and FSH in mice treated with antisera to LH and FSH on Day 5 of age

\begin{tabular}{ccc}
\hline $\begin{array}{c}\text { Age } \\
\text { (days) }\end{array}$ & $\begin{array}{c}\text { Binding to labelled } \\
\text { LH (\%) }\end{array}$ & $\begin{array}{c}\text { Binding to labelled } \\
\text { FSH (\%) }\end{array}$ \\
\hline 7 & - & - \\
10 & $282 \cdot 22$ & $155 \cdot 53$ \\
14 & $291 \cdot 77$ & $140 \cdot 75$ \\
17 & $254 \cdot 41$ & $135 \cdot 60$ \\
21 & $242 \cdot 58$ & $130 \cdot 40$ \\
28 & 226.84 & 91.43 \\
\hline
\end{tabular}

A $10-\mu 1$ sample of plasma was incubated with $1 \cdot 0 \mathrm{ng}{ }^{125} \mathrm{I}$-labelled LH or FSH.

The prolonged presence of antibodies has not been observed in adults (Morishige, Billiar \& Rothchild, 1975), and this may be due to the difference in metabolic clearance in neonatal animals or the relative immunological incompetence of the young compared with that of adults (Solomon, 1971).

We thank the NIAMDD, Bethesda, for the gift of hormones and radioimmunoassay kits. 


\section{References}

Anderson, C.H., Schwartz, N.B., Nequin, L.G. \& ELY, C.A. (1976) Effects of early treatment with antiserum to ovine follicle stimulating hormone and luteinizing hormone on gonadal development in the rat. Fert. Steril. 27, 47-58.

Avramaes, S. \& TernYNCK, T. (1969) The crosslinking of proteins with glutaraldehyde and its use for the preparation of immunoadsorbents. Immunochemistry 6, 53-64.

Beamer, W.G., Murr, S.M. \& Geshwind, H. (1972) Radioimmunoassay of mouse luteinizing and follicle stimulating hormones. Endocrinology 90, 823-827.

DOHLER, K.D. \& WuTTKE, W. (1974) Serum LH, FSH, prolactin and progesterone from birth to puberty in female and male rats. Endocrinology 94, 1003-1008.

DOHLER, K.D. \& WuTTKe, W. (1975) Changes with age in levels in serum gonadotropins, prolactin and gonadal steroids in prepubertal male and female rats. Endocrinology 97, 898-907.

DullaART, J., Kent, J. \& RYle, M. (1975) Serum gonadotrophin concentrations in infant female mice. J. Reprod. Fert. 43, 189-192.

Goldman, B.D., Grazia, Y.R., KamberI, I.A. \& PORTER, V.C. (1971) Serum gonadotropin concentration in intact and castrated neonatal rats. Endocrinology 88, 771-776.

KRAGT, C.L. \& DaHLgren, J. (1972) Development of neural regulation of follicle stimulating hormone secretion. Neuroendocrinology 9, 30-40.

Morishige, W.K., BILliaR, R.B. \& RoTHCHILD, I. (1975) Radioimmunologic assessment of the level of circulating LH antibodies after passive immunization in the rat. Endocrinology 96, 1437-1446.

OjedA, S.R. \& RAMIREZ, V.D. (1972) Plasma level of LH and FSH in maturing rats: response to hemigonadectomy. Endocrinology 90, 466-472.

Purandare, T.V., Munshi, S.R. \& RAO, S.S. (1976) Effect of antisera to gonadotropins on follicular development of mice. Biol. Reprod. 15, 311-320.

Sheridan, P.J., Zarrow, M.X. \& DenenberG, V.H. (1973) The influence of gonadotropins on the organization of the brain. In The Development and Maturation of the Ovary and its Functions, pp. 103116. Ed. H. Peters. Excerpta Medica, Int. Congr. Ser. No. 267, Amsterdam.

Soloman, J.B. (1971) Immunological tolerance. In Frontiers of Biology, Vol. 20, pp. 155-167. Eds A. Neuberger \& E. L. Tatum. Wiley interscience, New York.

Stiff, M.E., Bronson, F.H. \& Stetson, M.H. (1974) Plasma gonadotropins in prenatal and prepubertal female mice: disorganization of pubertal cycles in the absence of the male. Endocrinology 94, 492-496.

WeIsz, J. \& Ferin, M. (1970) Pituitary gonadotropins and circulating $\mathrm{LH}$ in immature rats: a comparison between normal females and males and females treated with testosterone in neonatal life. In Gonadotropins and Ovarian Development, pp. 339-350. Eds W. R. Butt, A. C. Crooke \& M. Ryle. Livingstone, Edinburgh.

Received 27 September 1976 